\title{
Microvertebrates from the Silurian-Devonian boundary beds of the Eastport Formation, Maine, eastern USA
}

\author{
Susan Turner and Carole J. Burrow* \\ Geosciences, Queensland Museum, 122 Gerler Road, Hendra, Queensland 4011, Australia \\ *Corresponding author <carole.burrow@gmail.com>
}

Date received: 13 November 2017 Date accepted: 27 January 2018

\begin{abstract}
Agnathan and gnathostome remains, associated with lingulid brachiopod fragments and distinctive ostracods, have been extracted from a small calcareous mudstone sample collected from the type section of the Eastport Formation on the northern shore of Moose Island, Maine. The vertebrate assemblage includes osteostracan, anaspid, and thelodont scales, and acanthodian scales, spines and teeth, which support a late Pridoli, or possibly earliest Lochkovian, age for the stratum. The thelodont Paralogania denisoni n. sp. is described, associated with a single thelodont scale referred tentatively to Talivalia? sp. indet., and acanthodians Nostolepis striata, Gomphonchus sandelensis, and Poracanthodes punctatus in a fauna that shows similarities to late Pridoli assemblages in Britain, parts of Europe, Russia, Greenland, and arctic Canada.

\section{RÉSUMÉ}

Les restes d'agnathes et de gnathostomes, associés à des fragments de brachiopodes lingulidés et à des ostracodes distinctifs, ont été extraits d'un petit échantillon de mudstone calcaire prélevé de la section type de la formation d'Eastport sur la côte nord de Moose Island, dans le Maine. L' ensemble d'animaux vertébrés comprend les ostéostracés, les anaspides, les écailles de thélodontes et les écailles, épines dorsales et dents d'acanthodiens, ce qui laisse penser que la strate date du Pridoli tardif ou du Lochkovien précoce. Le Paralogania denisoni n. sp. de thélodonte est décrit, en lien avec une seule écaille de thélodonte provisoirement appelée Talivalia? sp. indet., de même que les Nostolepis striata, Gomphonchus sandelensis et Poracanthodes punctatus d'acanthodiens, dans une faune qui montre des similarités avec des assemblages du Pridoli tardif de Grande-Bretagne, d'autres parties d'Europe, de Russie, du Groenland et de l'Arctique canadien.
\end{abstract}

[Traduit par la redaction]

\section{INTRODUCTION}

Few Silurian vertebrate sites have been described from the USA, and even fewer have been studied for vertebrate microfossils (hereafter microvertebrates) such as thelodont and acanthodian remains. The first record was of fin spines and heterostracans from Pennsylvania by Claypole (1884, 1885); he assigned the fin spines ("small spines apparently of Selachian fish": Claypole 1885, p. 426) to Onchus clintoni (Llandovery) and Onchus pennsylvanicus (Pridoli), and the poraspidid heterostracan shields and scales to Palaeaspis americana and Palaeaspis bitruncata. Other records from Pennsylvania were published by DeWindt (1974), who described purported acanthodian scales (actually thelodont scales) from upper Silurian beds of the Bloomsburg Formation, central Pennsylvania, and Giffin (1979), who published a full description of the thelodont scales from the same beds; her material is currently being re-assessed. One thelodont, a possible loganiid scale, was also reported from the Pridoli Dekker Formation (K. Denkler, pers. comm. to ST, 1990s, unconfirmed record). Turner et al. (1999) discovered older early Silurian microfossils of the thelodont Zuegelepis potanos from Illinois. Few other microvertebrate occurrences are known from the Silurian of the United States east coast; other possible records (e.g., Turner 1999), such as Thelodus sp. from Maryland, are also yet to be verified.

Abundant microvertebrate faunas have been described from arctic Canadian localities, particularly of thelodont assemblages (e.g., Märss et al. 2007), with rarer descriptions of late Silurian to Early Devonian acanthodians (Spjeldnaes 1967; Vieth 1980; Burrow et al. 1999; Burrow 2013). From eastern Canada, tolypelepid and corvaspid heterostracans have been reported from the middle Silurian Eramosa Lagerstätte, Ontario (von Bitter et al. 2007). From the late Silurian, Turner (1986) redescribed the only known articulated material of the thelodont type genus Thelodus and 
identified a Paralogania, as well as an acanthodian, from the Cunningham Creek Formation of southern New Brunswick; and Burrow (2011) described the latter as a new acanthodian Nerepisacanthus denisoni from the nodule horizon. Burrow et al. (2013) redescribed a microvertebrate fauna, including thelodonts and acanthodians, from the upper Silurian outcrops at Arisaig, Nova Scotia (first described by Legault 1968), and Burrow and Rudkin (2014) described an articulated specimen of Nerepisacanthus denisoni from the Bertie Formation of Ontario. Blaise et al. $(1990,1991)$ also recorded Thelodus parvidens and undetermined acanthodian scales from late Silurian sites in the Meguma terrane of Nova Scotia.

Relatively few middle Paleozoic fish remains are known from Maine (Churchill-Dickson 2004). Bastin and Williams (1914) mentioned a fish spine in a calcareous nodule from the Eastport Formation, and the acanthodian Nosto lepis sp. was recorded informally by Robert Denison (Churchill-Dickson 2004, table 1). Churchill-Dickson (2007) reviewed vertebrate records from the Silurian-Devonian of Maine, noting Silurian records of 'fish teeth' (probably conodonts) from the Edmunds Formation and acanthodian spines from the Ames Knob Formation, as well as Devonian placoderm remains ('Asterolepis') from the Chapman Sandstone. To date, other than the Denison material noted below, we have been unable to track down any of the vertebrate specimens previously reported.

Here we describe the microvertebrates from a sample (E-5) collected by the late Robert H. Denison in 1969 from the northern end of the type section of the Eastport Formation, west of Kendall Head along the northern shore of Moose Island, Maine (Fig. 1; approximate location $44.94^{\circ} \mathrm{N}$, $\left.-67.02^{\circ} \mathrm{W}\right)$.

\section{GEOLOGY}

The Eastport Formation of the Mascarene Group is part of the Coastal Volcanic Belt, a large volcaniclastic sequence

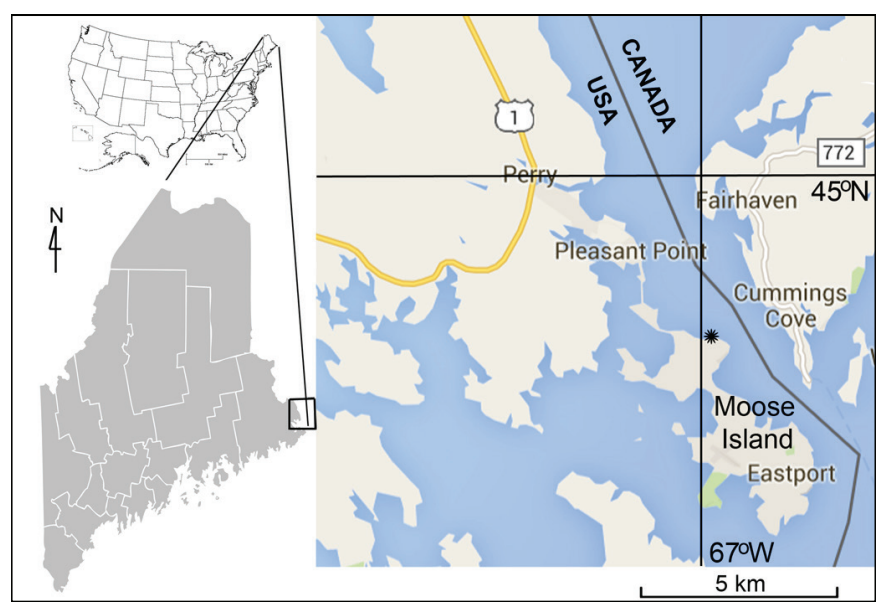

Figure 1. Map of Moose Island, Maine; asterisk indicates approximate sample E-1 locality. that extends from Massachusetts, USA, into New Brunswick, Canada (Fig. 2); the type locality is at Moose Island, Hancock County, Maine (Bastin and Williams 1914). The formation extends for more than $500 \mathrm{~km}$, and is approximately $2440 \mathrm{~m}$ thick in Maine according to Bastin and Williams (1914). The Eastport Formation is in a complex stratigraphic setting, with subareal volcanic rocks and shallow-water sedimentary rocks. Sedimentary rocks include: red siltstone; fine- to medium-grained sandstone; dark grey to green mudstone, siltstone and sandstone some with calcareous content; minor red polymictic conglomerate; and volcaniclastics. This succession represents deposition in a low-energy, peritidal environment, with volcanic rocks intercalated throughout the formation, predominating over the sedimentary rocks.

The Silurian succession in the coastal volcanic belt of Maine exhibits strong similarities to European Silurian sequences, a fact that troubled pre-continental-drift workers (Churchill-Dickson 2004). Previously the age of this succession had been regarded as wholly Early Devonian (Lochkovian or Pragian), based principally on an undescribed ostracod, which Berdan (1990) considered to belong to a quadrilobate beyrichiacean form allied to Cornikloedenina; but it is more like Carinokloedenia from the Pragian of Podolia and the Lochkovian of northern France. Subsequently, careful analysis of the known fossil data led Churchill-Dickson (2004) to conclude that the Eastport Formation is late Silurian (Pridoli) in age, an interpretation strengthened by the local stratigraphy, radiometric dating, and laser ablation on felsic tuffs and rhyolite flows at undisclosed levels in the formation; these provide dates ranging from $419(+/-6)$ to 436 (+/-6) Ma (Van Wagoner and Dadd 2003). This assessment also supported the age determined by earlier authors based on biostratigraphic correlations with European faunas (e.g., Claypole 1884: Bastin and Williams 1914).

Boucot et al. (1974) provided a general overview of regional geology and indicated that the marginal marine Eastport Formation was the local equivalent of the Knoydart Formation in Nova Scotia. The Eastport Formation interfingers with, and in some areas partially overlies, the Hersey Formation (Churchill-Dixon 2004, fig. 1), which conformably overlies the Pridoli Leighton Formation. In the east (including Moose Island), the Eastport Formation directly overlies the Leighton Formation (Fig. 2), and the uppermost levels are exposed on the north shore of Moose Island (Gates 1977). Boucot et al. (1974) described a fauna of bivalves, gastropods and ostracods, notably with few exclusively marine taxa. The low taxonomic diversity of the invertebrate fauna, which comprises leperditids and lingulid brachiopods, the gastropod Eurymyella, and eurypterid specimens, is suggestive of shallow marine to non-marine, perhaps estuarine or lagoonal, conditions (Boucot's BA1, as in Turner 1999).

The vertebrate remains described herein come from the same section as the 'fish spine' noted by Bastin and Williams (1914) and are associated with fragments of lingulid brachiopods and ostracod valves, some female with highly 


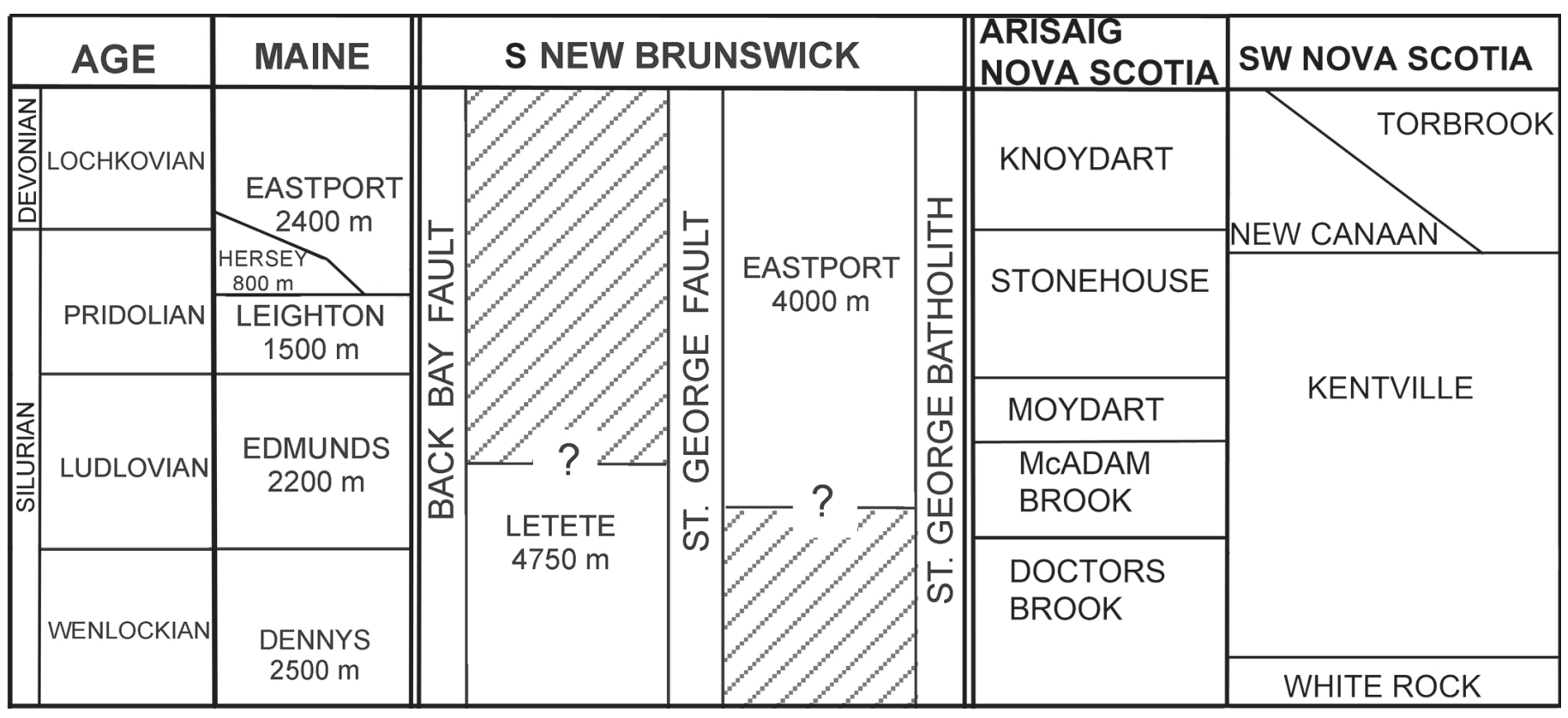

Figure 2. Stratigraphic columns for middle Silurian to Lower Devonian vertebrate-bearing deposits in Maine, southern New Brunswick, Arisaig in northern Nova Scotia, and southwestern Nova Scotia. After Miller and Fyffe (2002, fig. 3), Churchill-Dixon (2004), White and Barr (2012, fig. 2; 2017, fig. 17), and Burrow et al. (2013, fig. 1.3).

'bumpy' excrescences typical of shallow-water inshore settings (see Siveter 1989). No conodont elements have been recorded.

\section{MATERIALS AND METHODS}

The matrix of the sample is a dark-grey to green calcareous mudstone. The sample was processed using buffered $10 \%$ acetic acid. The microfossils are severely etched with a secondary crystallization apparent on the surface of the crowns. Uncoated specimens were imaged in a Hitachi Tabletop TM-1000 environmental scanning electron microscope (ESEM) at the Queensland Museum; several scales were immersed in anise oil to check histology where possible. All 150 specimens are reposited in the Field Museum of Natural History, Chicago (FMNH PF).

\section{SYSTEMATIC PALEONTOLOGY}

\author{
Class Osteostraci Lankester 1868-70 \\ Order indeterminate \\ Family indeterminate
}

\begin{tabular}{c} 
Genus indeterminate \\
\hline Species indeterminate
\end{tabular}

(Figs. 3a-d)

Material. Scale or dermal bone fragments, fewer than ten including PF 16479, 16480.
Description. Only fragments of scales, or more probably the outer layer of head shield tesserae, are preserved. The base is thin; the ornament comprises short high narrow ridges with smooth rounded crests. The ridges are $0.5 \mathrm{~mm}$ or more long, and closely spaced pores open out on the base between the ridges.

Remarks. Cephalaspids (= osteostracans) from the Lochkovian MOTH locality of the Northwest Territories were described by Dineley and Loeffler (1976) and Adrain and Wilson (1994), but none has an ornament that closely resembles the Eastport Formation specimens. Osteostracans with similar ornament are found in the lower Old Red Sandstone facies (Pridoli-Lochkovian) of the Welsh Borderland and the Baltic (e.g., Gross 1961; Turner et al. 2017). The Maine specimens are most similar to Ohesaareaspis (?order Cephalaspidiformes, family indet.), Tahulaspis (order Tremataspidiformes), and Thyestes (family Thyestidae) (Märss et al. 2014, figs. 46F, 37C, 30F, L) from the Silurian (Ludlow-Pridoli) of Saaremaa Island, Estonia.

Class Anaspida Traquair 1899

Order Birkeniida Berg 1937

Family Rhyncholepididae Kiaer 1924

Genus Schidiosteus Pander 1856
Schidiosteus mustelensis Pander 1856
(Figs. 3e-f)

Material. Fewer than ten fragments, including PF 16481 and 16482. 


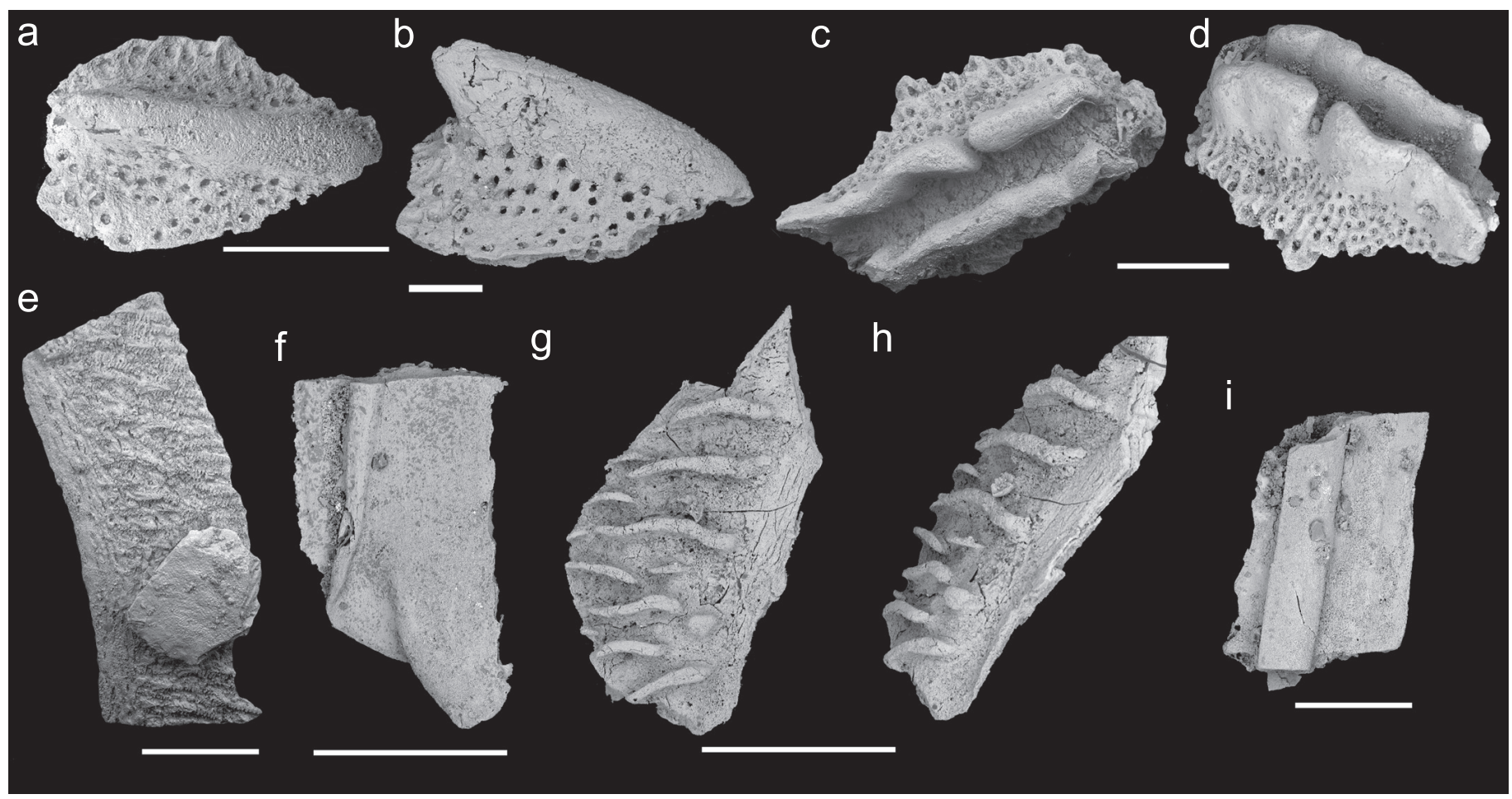

Figure 3. ESEM images of osteostracan and anaspid agnathan scale fragments from the Eastport Formation, Maine. (a and b) Osteostraci gen., sp indet. PF 16479, scale bar $=0.5 \mathrm{~mm}$. (c and d) Osteostraci gen., sp. indet. PF 16480, scale bar $=0.5$ mm. (e) anaspid Schidiosteus mustelensis PF 16481 sculpture surface, scale bar $=1 \mathrm{~mm}$. (f) anaspid Schidiosteus mustelensis PF 16482 visceral surface, scale bar $=1 \mathrm{~mm}$. (g and $\mathrm{h}$ ) anaspid Septentrionia? sp. PF 16483 sculpture surface, scale bar $=$ $1 \mathrm{~mm}$. (i) anaspid Septentrionia? sp. PF 16484 visceral surface, scale bar $=0.5 \mathrm{~mm}$.

Description. These few, incomplete scales have a flat anterior (overlap) margin lacking ornament. The ornament on the free field comprises several oblique rows of low ridges formed of close-set overlapping chevrons. The ridges are closely spaced and oriented subparallel to each other. Vascular canal openings occur between the ridges and on the flat anterior margin. The medial rib on the inner surface is well developed.

Remarks. Although the ornament is poorly preserved, it closely resembles the distinctive scale ornament of short, wide triangular or heart-shaped sculptural elements in closely spaced or overlapping regular rows for Schidiosteus mustelensis (the type and only species of Schidiosteus), as illustrated by Blom et al. (2002, fig. 30). The taxon is known from: the middle Ludlow of Saaremaa, Estonia; the late Wenlock to early Ludlow of Gotland, Sweden, and Severnaya Zemlya, Russia; and the Ludlow of the central Urals, Russia.

Family Septentrioniidae Blom, Märss and Miller 2002

Genus Septentrionia Blom, Märss and Miller 2002

Septentrionia? sp.

(Figs. 3g-i)

Material. Fewer than ten fragments, including PF 16483, 16484.
Description. The scales have a sparse ornament comprising nine to ten subparallel, short and long ridges extending obliquely across the scale, with rare rounded tubercles near the anterior margin. The ridges are smooth, narrow and high, and widely separated. Only a few vascular canals open out on the interridge areas and posterior to the medial visceral ridge, which is robust. The ventral surface (Fig. 3i) has a distinct raised lateral curvature.

Remarks. The scale ridges are more sparsely distributed than on previously figured scales of Septentrionia spp. from the Ludlow to Lochkovian of the Welsh Borderland, Arctic Canada, northern Greenland, the Baltic, and the central Urals of Russia (Blom et al. 2002, figs. 43-47). The Eastport Formation scales are most similar to scales of Septentrionia lancifera (Blom et al. 2002, figs. 43X-Y) from Man Brook in the Welsh Borderlands (late Pridoli; see also Turner et al. 2017).

Class Thelodonti Jaekel 1911

Order Shieliiformes Märss, Wilson and Thorsteinsson 2002

?Family Shieliidae Märss, Wilson and Thorsteinsson 2002

Remarks. The family is based on the taxon Shielia taiti (Stetson, 1931) from the Wenlock Fish Bed Formation, Glenbruck Group, of Shiel Burn, Scotland. It comprises a group 
of mainly Silurian spiny-scaled thelodonts, including the genera Nethertonodus, Praetrilogania, Valiukia and Paralogania (Märss et al. 2007). See Table 1 for a geographic and stratigraphic overview of known Paralogania species.

Genus Paralogania Karatajūtè-Talimaa 1997

Paralogania denisoni sp. nov.

(Figs. 4a-r, 5)

Material. About 30 poorly preserved grey-black to chalky scales, some fragile, including PF 16485-16493; nearly all are trunk scales.

Holotype. FMNH PF 16486 (Figs. 4c-d, 5a-b).

Etymology. In honor of the late Robert (Bob) Denison, who made the first discovery of the fish microfossils in Maine.

Diagnosis. Paraloganiid with small to medium-sized scales, $\sim 0.3-1.0 \mathrm{~mm}$. Trunk scales lozenge-shaped, generally flattened and elongate with an anterior basal prong up to third scale length; crown high, relatively narrow and rounded anteriorly with a wide flat neck region; high median section flanked with one or more lateral ridges ending in three to five separated posterior points and at least three postero-ventral ribs below them and anteriad to the posterior basal rim; up to nine lateral lappets with an odd number on each side of scale. Base wider than crown; basal surface flattened with shallow pulp cavity with median groove, ending posteriad in a shallow depression. Dentine canal openings concentrated in the pulp groove.

Description. Most of the thelodont scales in the sample are presumed to be trunk scales (Figs. 4a-i, l-m, 5a-b), of which the holotype scale is well preserved, with posterior points from at least five separated posterior lappets (Figs. 4e-f, 5b). There are no definite rounded oral scales (sensu Märss et al. 2007), but some relatively wide scales (Figs. $4 \mathrm{j}-\mathrm{k}, \mathrm{n}-\mathrm{o}$, 5q-r) are possibly cephalo-pectoral or from the leading edges of the pectoral fins. One very small scale, around $0.3 \mathrm{~mm}$, has a short-ribbed crown on a deeper rounded base, with well-preserved lateral lappets (Figs. 4q-r, 5c); it may be a pinnal scale. The separation of the posterior ribs with clear long notches (Figs. $4 a-b, d, g-h, 5 a)$ is an unusual feature in this species, and may have been accentuated during preservation. The neck is narrow and trough-like in most trunk scales, being wider in those with a wider base (e.g., Figs. $4 j-k, n-p)$. The base in most specimens is shallow in height and as long as or longer than the crown. Generally the scales are flat on the basal surface; only in the smaller scale (Figs. $4 \mathrm{q}-\mathrm{r}$ ) is the base deeper and shorter than the crown. There is anterior thickening or an elongated extension or rootlet/ prong in most scales (e.g., Figs. 4g-i, 5a-b).

The lack of a shiny surface to the scale crowns, their chalky appearance, and the transparency of some of the lappets and ribs suggest that the scales have been metamorphosed to some extent and that the dentine and basal aspidin is worn (Turner 1994). The posterior points of the crowns and lateral riblets are mostly broken.

Histology. The scales are not well enough preserved to obtain any detailed histological information, but in general the style of base with an elongate pulp cavity or slit is suggestive of a loganiid or paraloganiid scale, the latter now placed within the Sheiliiformes (e.g., Žigaite et al. 2013a). The number and expression of any basal dentine canals is unclear, but there may be at least three in the posteriad depressed area of the base.

Remarks. These spiny scales fall within the Paralogania group, which currently includes taxa from the middle to late Silurian and earliest Lochkovian of Laurentia (Märss et al. 2007; Table 1). The scales from Maine seem closest to Paralogania readbayensis Märss et al. 2002 from poorly constrained lowermost Lochkovian of arctic Canada, and to Paralogania kummerowi (Gross 1967) known from the late Pridoli of Europe, where it is a key zone fossil (e.g., Turner et al. 2017).

Order Thelodontiformes Kiaer 1932

?Family Talivaliidae Märss, Wilson \& Thorsteinsson 2002

Remarks. This family is based on scales of the former $\mathrm{Ni}$ kolivia elongata Karatajūte-Talimaa, 1978 known from the Lochkovian of many localities in the Baltic countries, Russia, Spitsbergen, Britain, arctic Canada and Nevada. At present, it includes Talivalia, Glacialepis and Amaltheolepis (Märss et al. 2007). The Maine scale resembles some referred to the type species Talivalia (Nikolivia) elongata (e.g., Märss et al. 2007, fig. 130 and see below).

Genus Talivalia Märss, Wilson \& Thorsteinsson 2002

Talivalia? species indeterminate (Figs. 4s-u)

Material. PF 16494; one scale.

Description. Elongate, spine-like, poorly preserved specimen of around $1 \mathrm{~mm}$ in length with a smooth upper surface ornamented with four or five pairs of fine double ribs on the crown. These fine raised striae are separated by a narrow trough. Each raised ridge is flanked by smooth areas wider than ridge (Figs. $4 s-t)$. The anterior end is gently rounded. The posterior point is broken, revealing a gently curved cross-section. The neck is so shallow as to be almost non-existent. The base has a relatively thickened anterior rim. The basal surface is unclear but appears to be very shallow with an ovoid, wide-open pulp cavity leading posteriorly into the damaged central pulp canal (Fig. $4 \mathrm{u}$ ).

Histology. The posterior end of the scale is broken, expos- 


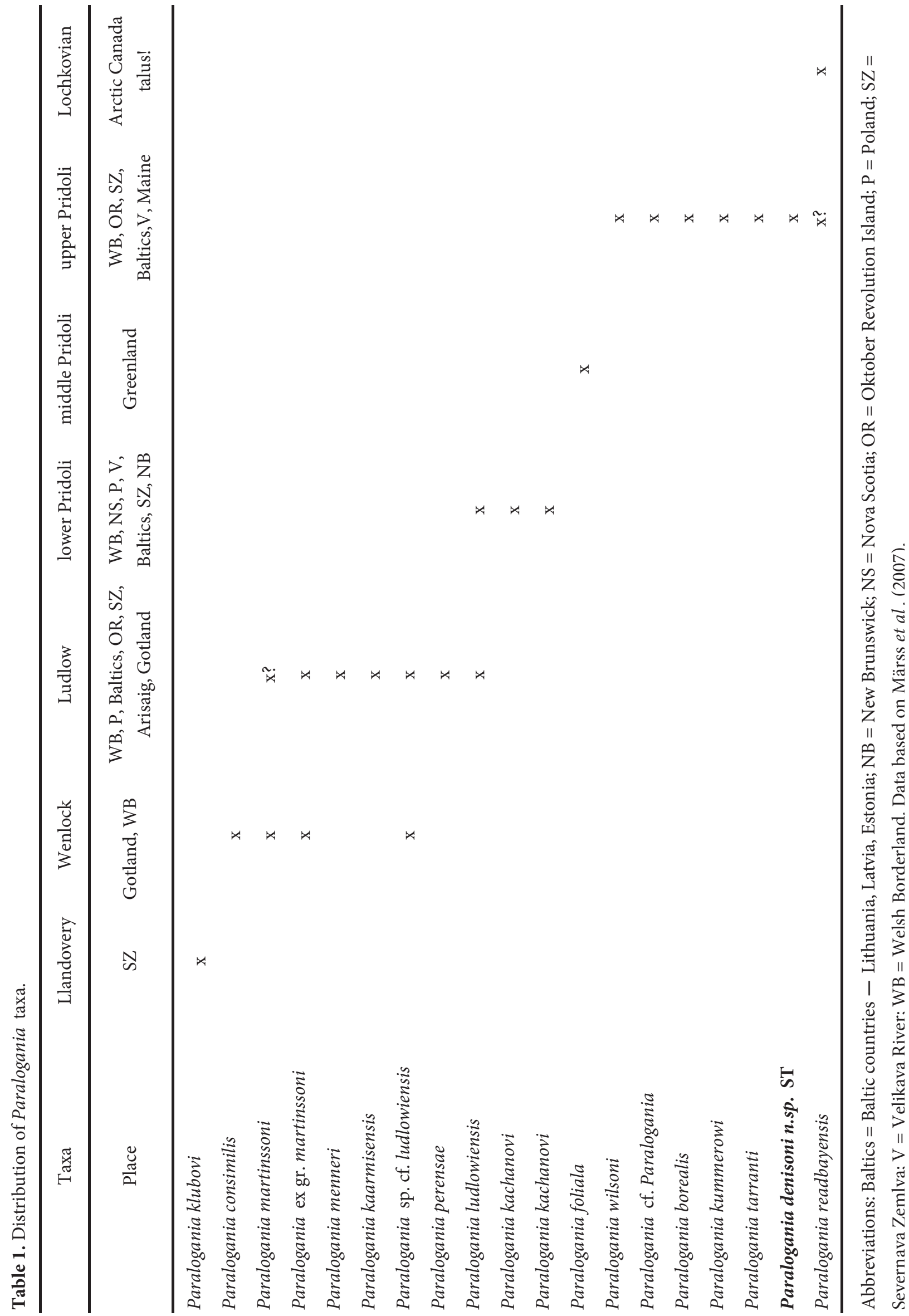




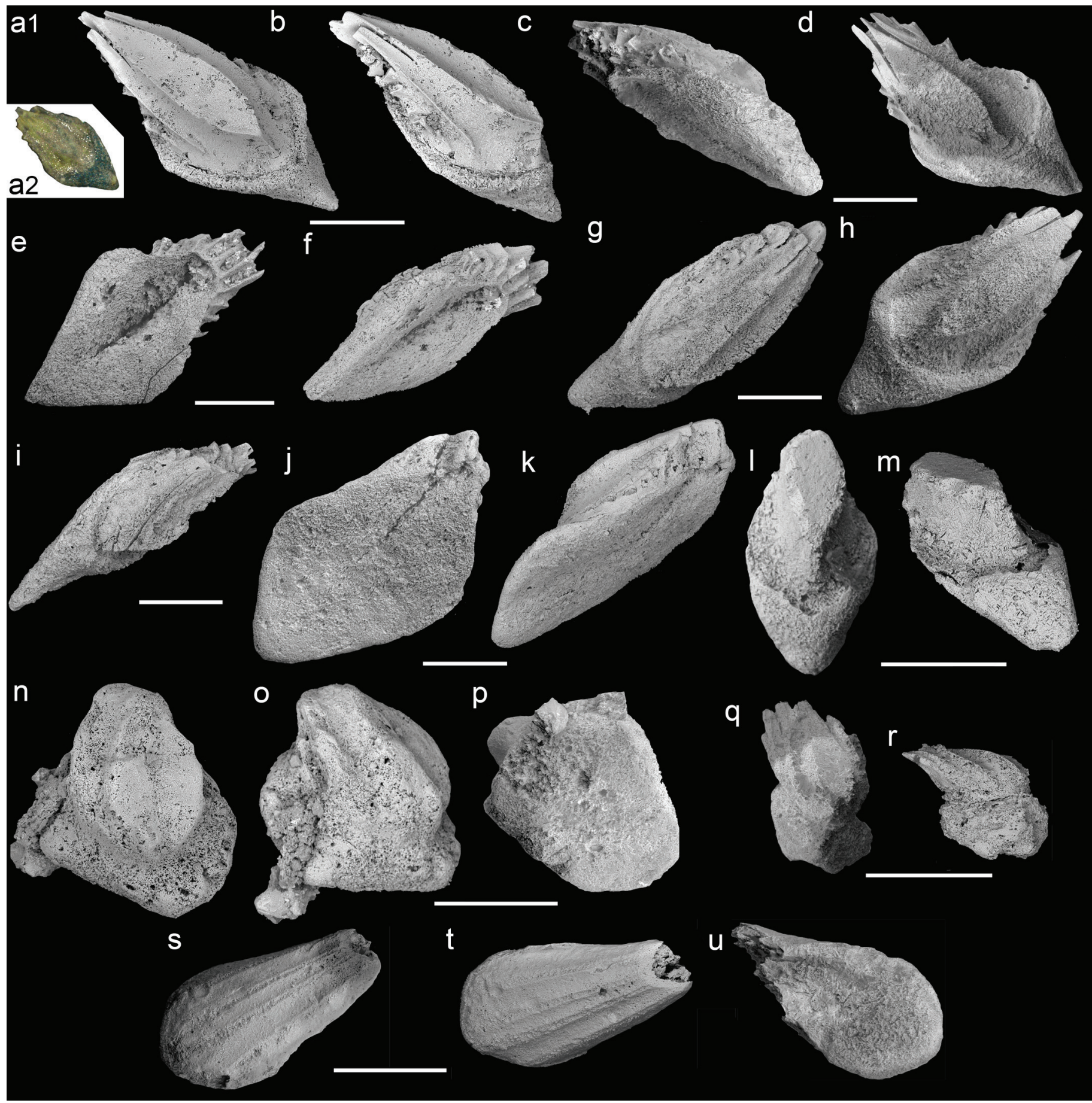

Figure 4. ESEM images of thelodont agnathan scales from the Eastport Formation, Maine. (a and b) Paralogania denisoni n. sp., PF 16485, scale bar $=0.3 \mathrm{~mm}$ : a1 in crown view, a2 = light microscope to show style of preservation). (c and d) Paralogania denisoni n. sp., holotype trunk scale PF 16486 in posterolateral and crown views, scale bar $=0.3 \mathrm{~mm}$. (e and f) Paralogania denisoni n. sp., PF 16487 in ventral and posterolateral views, scale bar $=0.3 \mathrm{~mm}$. (g and h) Paralogania denisoni $\mathrm{n}$. sp., PF 16488 in dorsolateral and dorsal views, scale bar $=0.3 \mathrm{~mm}$. (i) Paralogania denisoni n. sp., PF 16489 in dorsolateral view, scale bar $=0.3 \mathrm{~mm}$. (j and k) Paralogania denisoni n. sp., PF 16490, scale bar = $0.3 \mathrm{~mm}$. (1 and $\mathrm{m})$ Paralogania denisoni n. sp., PF 16491, scale bar = 0.3 mm. (n-p) Paralogania denisoni n. sp., PF 16492, scale bar = 0.3 mm. (q and r) Paralogania denisoni n. sp., PF 16493 possible pinnal scale in anterodorsal and lateral views, scale bar $=0.3 \mathrm{~mm}$. (s-u) Talivalia? sp. indet., PF 16494 in dorsal, posterolateral and ventral views, scale bar $=0.3 \mathrm{~mm}$. 
a

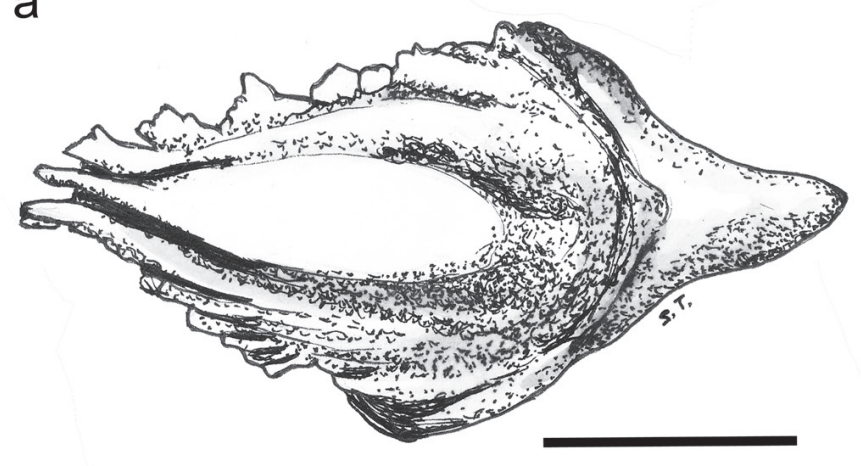

b

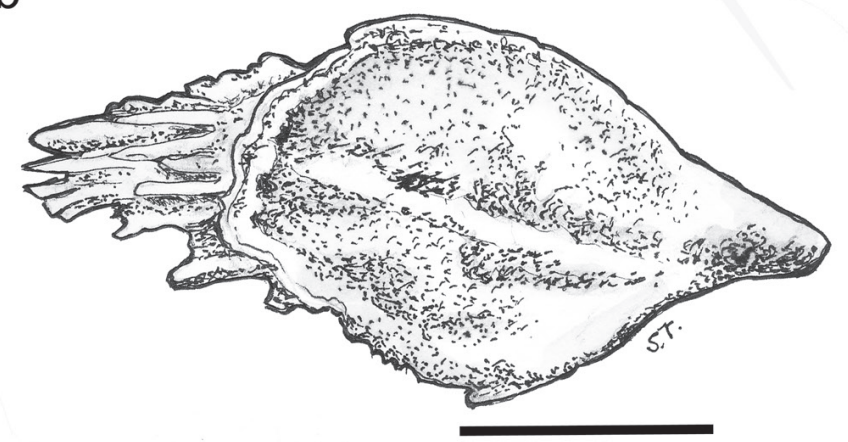

C

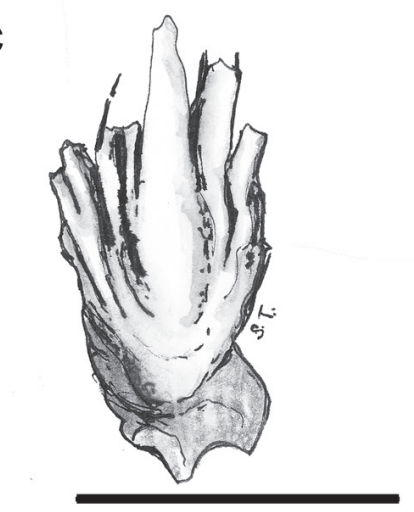

e

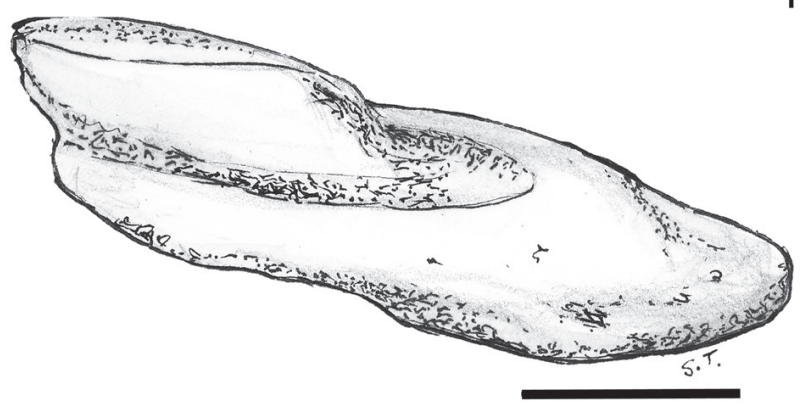

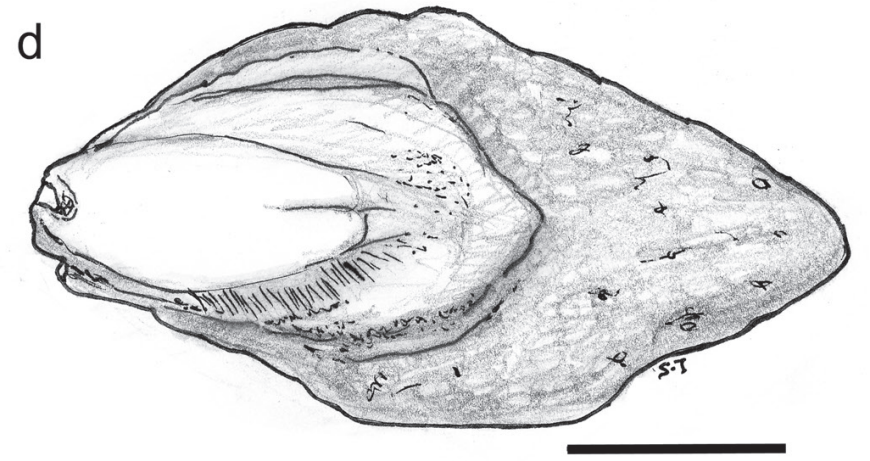

f

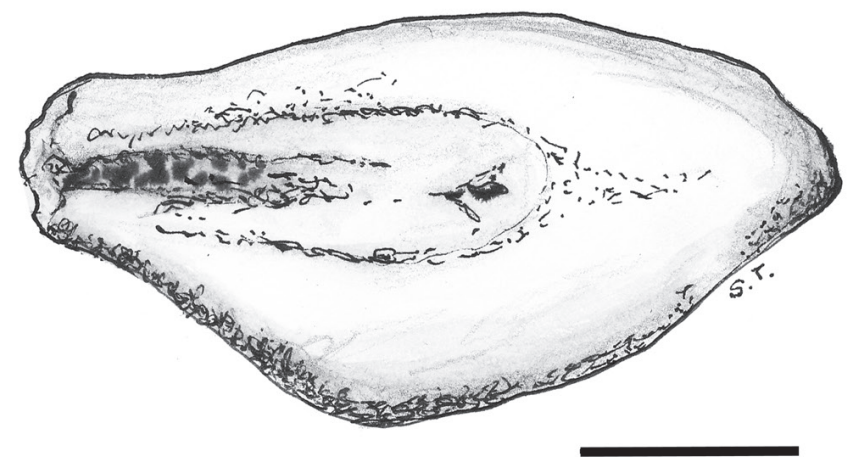

Figure 5. Thelodont agnathan Paralogania denisoni n. sp. scales from the Eastport Formation, Maine; drawings by ST. (a and b) PF 16489 (Figs. 4c-d), scale bar = $0.3 \mathrm{~mm}$. (c) PF 16493 (Figs. 4q-r), scale bar = $0.3 \mathrm{~mm}$. (d-f) PF 16490 (Figs. 4j-k), scale bar $=0.3 \mathrm{~mm}$.

ing the internal structure of the crown dentine. The general form of the scale suggests a thelodontiform affinity.

Remarks. The Maine specimen is comparable to the trunk scale shown by Märss et al. (2006, fig. 56P) from the lower Lochkovian Barlow Inlet Formation of Cornwallis island, and others figured by Dineley and Loeffler (1976, text-fig. 65) from the Delorme Formation, Mackenzie River district, Northwest Territories, Canada, and some Talivalia elongata scales from the basal Lochkovian of Earnstrey Brook and other Brown Clee Hill localites in Shropshire, England (Turner 1973, 1984; Turner et al. 2017). The Maine specimen might be an immature scale based on its wide and shallow pulp opening.

Based on the squamations of established Paralogania species (e.g., Märss et al. 2007), this specimen does not fit into the probable scale variation of Paralogania denisoni. Instead, it is tentatively referred to the genus Talivalia based on its overall scale form. It also resembles the trumpet-shaped scales of the older Wenlock Nunavutia (Märss et al. 2006) and of younger Lochkovian to Eifelian Talivalia and Amaltheolepis species (Märss et al. 2007, Žigaite et al. 2013b). However, it differs in that the striae of the crown are separated by narrow troughs rather than being raised ridges. This might be a taphonomic factor, with the denser dentine surface of the ridges worn away, although such a style of preservation has not been observed before except in the ridges of similarly dated Turinia nachoi trunk scales from Spain (e.g., Märss et al. 2007, figs. 113J, K). The genus Talivalia is not known below the lowest Lochkovian, but this may not preclude the possibility that it or a closely related form might appear earlier, in the late Pridoli.

More material is needed to assess details of histology and relationships. Hence for now we leave the generic assignment as tentative and the species as indeterminate. More material is needed to assess details of histology and relationships. 
Superclass Gnathostomata Gegenbauer 1874

Class Acanthodii Owen 1846

Order indeterminate

Family indeterminate

Genus Nostolepis Pander 1856

Nostolepis striata Pander 1856

(Figs. 6a-e)

Material. Five scales including one body scale PF 16495 and one pinnal scale 16496, plus one spine fragment PF 16497.

Description. The body scale (Figs. 6a-b) is about $0.6 \mathrm{~mm}$ long and wide, and $0.4 \mathrm{~mm}$ deep with seven short ridges leading back from the anterior margin of the scale crown, and two narrow ledges at a lower level along the posterolateral sides of the crown. The crown is slightly inclined anterior to posterior, with a negligible neck between the rounded anterior margin and the scale base. The scale base is convex and shallow. The pinnal scale or tessera (Figs. $6 \mathrm{c}-\mathrm{d}$ ) has a sharply pointed crown/tubercle comparable to a typical crown that has been tilted vertically, on a thin flat subcircular base. The small spine fragment has longitudinal ridges with long smooth nodes.

Remarks. The body scale resembles the type scale of Nosto lepis striata (Pander 1856, pl. 6 fig. 7) from the Pridoli Ohesaare Formation, Saaremaa Island, Estonia; the scales and spine fragment also closely resemble elements assigned to Nostolepis striata by Gross $(1947,1971)$. Although Valiukevičius (e.g., 2003a, b) has since split this taxon into more species, the few body scales from the Eastport Formation match those still regarded as Nostolepis striata s.s. - i.e., scales with the same morphology as those illustrated by Pander (1856). As these are the only recognizable acanthodian scales in the sample that are not ischnacanthiform, it seems reasonable to allocate the few other elements - the pinnal scale and noded spine fragment - that match those known to occur in Nostolepis to the same species. Nostolepis species that have been recorded from the Silurian-Lochkovian of eastern and arctic North America include: Nostolepis striata from the late Silurian Stonehouse Formation, Arisaig, Nova Scotia (see Burrow et al. 2013) and late Silurian-Lochkovian of the Canadian Arctic Archipelago (Vieth 1980; Märss et al. 1998); and Nostolepis arctica, Nostolepis applicata and Nostolepis multicostata from the Lochkovian of the Canadian Arctic Archipelago (Vieth 1980). Nostolepis arctica is characterized by long narrow crowns, Nostolepis applicata has a crown formed of overlapping petal-like growth zones, and Nostolepis multicostata has a large number of close-set, irregularly spaced ridges covering the crown; none of these characters are seen in the resent material. The only Nostolepis striata scale figured by Vieth $(1980, \mathrm{pl} .5 .18,19)$ is a placoderm scale, and Märss et al. (1998) did not figure any material, so it is uncertain whether Nostolepis striata sensu stricto occurs in these assemblages. Nostolepis striata has been reported from upper Silurian to Lower Devonian deposits almost worldwide, but it seems likely that at least some of these records are from one of the other morphologically similar species.

Order Ischnacanthiformes Berg 1940

Family Ischnacanthidae Woodward 1891

Genus Gomphonchus Gross 1971

Gomphonchus sandelensis (Pander 1856) (Figs. 6f-g)

Material. Ten scales, including PF 16498, 16499.

Description. The scale PF 16498 (Figs. 6 f-g) has a smooth flat crown that is slightly wider than long, a neck that is concave all round, and a convex base that protrudes slightly in front of the crown; the neck and base are of similar height, with the scale being about $0.4 \mathrm{~mm}$ long, $0.5 \mathrm{~mm}$ wide, and $0.4 \mathrm{~mm}$ deep. The other scale (PF 16499) assigned to Gomphonchus sandelensis is more poorly preserved and incomplete, but also has a smooth flat crown.

Remarks. The symmetrical body scale(s) compares closely in morphology and size to the type scale (Pander 1856, pl. 6 figs. 15-17) from the Pridoli Ohesaare Formation, Saaremaa Island, Estonia. The species is widespread through the Pridoli-Lochkovian of the circum-Arctic region, being recorded from: the Canadian Arctic; Lithuania, Latvia, Estonia, Sweden and northern Germany; Sweden; Severnaya Zemlya and Timan-Pechora, Russia; Welsh Borderland, U.K.; and possibly Greenland (e.g., Gross 1971; Vieth 1980; Märss et al. 1998; Blom 1999; Vergoossen 2000; Valiukevičius 2003a), as well as from Spain (Mader 1986, fig. 8, pl. 1 figs. 1, 2).

Family Poracanthodidae Vergoossen 1997

Genus Poracanthodes Brotzen 1934

Poracanthodes punctatus Brotzen 1934

(Figs. 6h-s)

Material. Sixty-five scales, including figured scales PF 16500-16507.

Description. The scales are less than $1.0 \mathrm{~mm}$ long, of almost equal width and length, with a flat horizontal crown lacking ornament ribs or ridges, but penetrated by an extensive coverage of small-caliber canals (Figs. $6 \mathrm{~h}-\mathrm{p}$ ). The neck is deep and concave all round, delimited from the shallow, convex base by a marked rim (Figs. 6h-i). The poor preservation of the scales, with hyphal borings extending into canals within the scales, has exposed the details of the distribution of dentine tubules, and also pore canals aligned with the growth zones in the upper crown (Figs. 6j-p), leading into the larger radial and arcade canals. The borings and erosion of the wider 


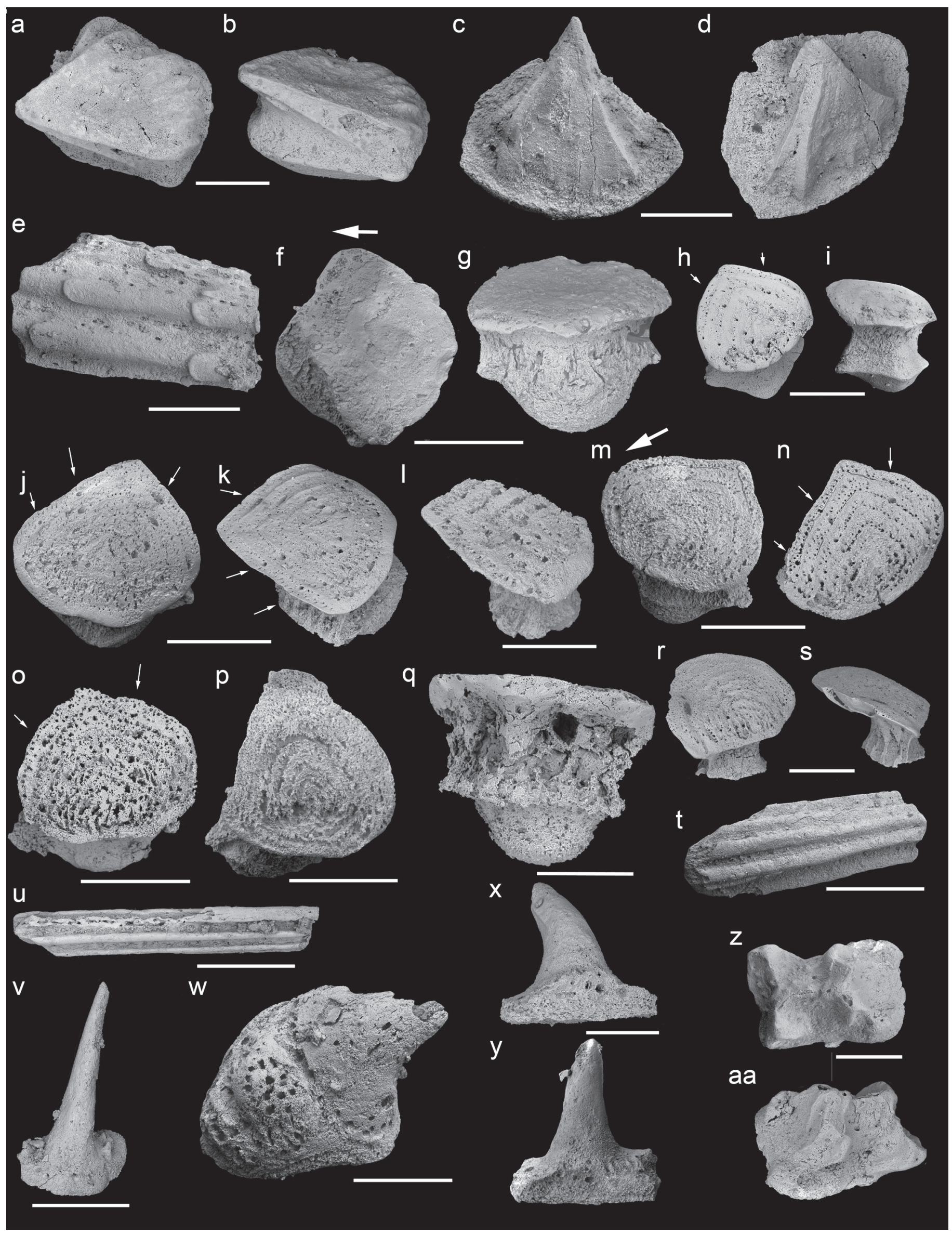


Figure 6. (previous page) Gnathostome remains from the Eastport Formation, Maine; ESEM images. (a and b) Nostolepis striata scale PF 16495 in crown and posterolateral views, scale bar $=0.3 \mathrm{~mm}$. (c and d) Nostolepis striata pinnal scale PF 16496 in ?anterior and lateral views, scale bar $=0.3 \mathrm{~mm}$. (e) Nostolepis striata spine fragment PF 16497, scale bar $=0.5 \mathrm{~mm}$. (f and g) Gomphonchus sandelensis scale PF 16498 in crown and anterior views, scale bar $=0.3 \mathrm{~mm}$. (h and i) Poracanthodes punctatus scale, PF 16500 in crown and anterior views, scale bar $=0.3 \mathrm{~mm}$. ( $\mathrm{j}$ and $\mathrm{k}$ ) Poracanthodes punctatus scale, PF 16501 in crown and laterocrown views, scale bar $=0.3 \mathrm{~mm}$. (1) Poracanthodes punctatus scale, PF 16502 in laterocrown view, scale bar $=0.3 \mathrm{~mm}$. ( $\mathrm{m}$ and $\mathrm{n})$ Poracanthodes punctatus scale, PF 16503 in anterocrown and crown views, scale bar $=$ $0.3 \mathrm{~mm}$. (o) Poracanthodes punctatus scale, PF 16504 in crown view, scale bar $=0.3 \mathrm{~mm}$. (p) Poracanthodes punctatus scale, PF 16505 in crown view, scale bar $=0.3 \mathrm{~mm}$. (q) Poracanthodes punctatus scale, PF 16506 in posterior view showing large canal openings, scale bar $=0.2 \mathrm{~mm}$. ( $\mathrm{r}$ and s) Poracanthodes punctatus scale, PF 16507 in anterocrown and lateral views, scale bar $=0.5 \mathrm{~mm}$. ( $\mathrm{t}$ ) ischnacanthiform fin spine fragment PF 16508, scale bar $=1.0 \mathrm{~mm}$. (u) ischnacanthiform fin spine fragment PF 16509, scale bar $=1.0 \mathrm{~mm}$. (v) ischnacanthiform Dornzähn PF 16510, scale bar $=0.5 \mathrm{~mm}$. (w) acanthodian tooth whorl PF 16511 in occlusal view, scale bar $=0.5 \mathrm{~mm}$. ( $\mathrm{x}$ and $\mathrm{y}$ ) acanthodian tooth PF 16512 in posterior and anterior views, scalebar $=0.3 \mathrm{~mm}$. ( $\mathrm{z}$ and aa) acanthodian or placoderm scale or tessera fragment PF 16513 in crown and lateral views, scalebar $=0.3 \mathrm{~mm}$. Anterior of scales to right unless indicated by large arrows; small arrows indicate position of radial pore canals.

pore canals expose the position of the underlying radial canals in many scales (Figs. 6i-o). The smaller pore-canal openings are slit-like and oriented antero-posteriorly (Figs. $6 j-1)$. Other than the smallest scales which have only two radial canals (Fig. 6h), all larger scales appear to have four radial canals, opening out as wide pores under the posterior overhang of the crown (Fig. 6q). Scale PF 16507 (Figs. 6r-s) differs from the normal body scales in having a flat base and an inclined crown.

Remarks. Despite their poor preservation, the scales can be readily assigned to Poracanthodes puncatus by the characteristic distribution of pore openings in lines paralleling the straight growth-zone borders on the crown surface. Vergoossen (1999) proffered a diagnosis for the species in which he noted that the scales have a pore-canal-free zone close to the anterior edge of the crown and a pore-canal system that usually only starts in the fourth or fifth growth zone. Erosion of the crown surface on the Maine scales has exposed dentine canals/tubules as well as pore canals, but it does appear that the evenly spaced, slit-like openings of the pore canals running up from the non-exposed arcade canals are only developed in the outermost growth zones (Figs. 6k, n). Vergoossen (1999) also observed that Devonian forms of Poracanthodes punctatus have only two to four radial canals, whereas Silurian forms have up to ten. However, the Maine scales are in the smaller size range for the species, and the number of canals is probably a result of their size rather than stratigraphic age.

Poracanthodes punctatus is widespread through the late Silurian to Early Devonian of the circum-Arctic region, having been described from Lithuania, Latvia, Estonia, Sweden, northern Germany, Welsh Borderland, Greenland, arctic Canada, and Severnaya Zemlya (e.g., Gross 1971; Blom 1999; Burrow et al. 1999; Vergoossen 2000; Valiukevičius 2003c). Despite being originally nominated as a zone fossil for the late Pridoli (Märss et al. 1995), Poracanthodes punctatus has been described from older Ludlow deposits (Valiukevičius 2003c; Vergoossen 1999). Its long stratigraphic range, and variations in morphology and histology, could indicate that the taxon encompasses more than one species.
Family Ischnacanthiformes Berg 1940

\begin{tabular}{c}
\hline Genus indeterminate \\
$\begin{array}{c}\text { Species indeterminate } \\
\text { (Figs. } 6 \mathrm{t}-\mathrm{v})\end{array}$
\end{tabular}

Material. Ten spine fragments, including PF 16508, 16509; one tooth - PF 16510.

Description. The spine fragments (Figs. 6t-u) have rounded, smooth longitudinal ridges about $0.2 \mathrm{~mm}$ wide, separated by similar width or narrower grooves. The leading edge ridge on PF 16509 (Fig. 6u) is slightly wider than the lateral ridges. PF 16510 (Fig. 6v) is a tall, smooth tooth on a thin circular base; the base has a ring of tiny denticles around the base of the tooth.

Remarks. The spine fragments are too incomplete to be assigned more accurately, but as the scales in the sample are either ischnacanthiform or Nostolepis striata, it is likely that the spines are also ischnacanthiform. As Nostolepis striata has noded ridges on the spines, by default the spine fragments with smooth ridges are considered to be ischnacanthiform. The tooth PF 16510 is the same type of element that Gross (1957, pl. 3.1-3; pl. 4.1-3) described as "Dornzähn of Gomphodus" (= 'thorn' teeth; the taxon is now Gomphonchus). At the time that Gross wrote, Poracanthodes was considered a form taxon for sensory line scales of Gomphonchus, but since the description by Valiukevičius (1992) of articulated fish with Poracanthodes-type scales, Poracanthodes is now recognized as a biological taxon. Dornzähn could derive from various ischnacanthiforms, not just Gomphonchus. 
Order indeterminate

Family indeterminate

Genus indeterminate
Species indeterminate

(Figs. 6w-y)

Material. One tooth whorl PF 16511, one tooth whorl fragment PF 16512.

Description. The near complete tooth whorl (Fig. $6 \mathrm{w}$ ) is poorly preserved, but has a subtriangular base with one smooth conical tooth and two rounded nubs forming the whorl; algal or fungal hyphal borings in the nubs indicate these are penetrated by a network of vascular canals. The fragment (Figs. 6x-y) has a recurved tooth about $0.5 \mathrm{~mm}$ high, with weak lateral ridges towards the apex, ankylosed to a broken base about $0.2 \mathrm{~mm}$ deep. The fracture surfaces through the base show multiple canals leading up into the tooth.

Remarks. The tooth whorls resemble those known from many late Silurian and Early Devonian localities worldwide, and could derive from ischnacanthiforms, or other acanthodians with a dentition comprising multiple tooth whorls (see comments in Burrow et al. 2013).

Class indeterminate

Order indeterminate

Family indeterminate

\begin{tabular}{c}
\hline Genus indeterminate \\
\hline Species indeterminate
\end{tabular}

(Figs. 6z, aa)

Material. Scale or tessera PF 16513.

Description. The scale(?) fragment is $0.25 \mathrm{~mm}$ long, 0.15 $\mathrm{mm}$ wide, and has a flat base. The crown ornament comprises four stellate tubercles.

Remarks. The scale could be part of an acanthodian stellate tessera like those that Gross (1971) assigned to Nostolepis striata. Alternatively, it could be an acanthothoracid placoderm scale (see Burrow and Turner 1999).

\section{DISCUSSION}

\section{Age}

The presence of osteostracan, anaspid, thelodont, acanthodian and possible placoderm remains in the Eastport Formation of Maine mirrors the vertebrate fauna known elsewhere in the Lower Old Red Sandstone of eastern North America and Europe (e.g., Denison 1956; the 'Cephaslaspid province of Young 1981; the North Atlantic province of Dineley and Loeffler 1993; and the 'central Appalachian zone' of Blieck and Janvier 1999, Burrow et al. 2013 and Turner et al. 2017). A similar faunal assemblage is also known from the latest Silurian marine limestones of the Canadian Arctic Archipelago (Märss et al. 1998).

The osteostracan and anaspid remains are not readily identified to species level, particularly with so few specimens; but they generally resemble those from the late Silurian - Early Devonian Old Red Sandstone facies (e.g., Denison 1956; Blom et al. 2002; Turner et al. 2017).

The new species, Paralogania denisoni, most closely resembles such species as Paralogania readbayensis known from talus below the southern section of the Barlow Inlet Formation, Read Bay, eastern Cornwallis Island, arctic Canada (?possible late Pridoli to lower Lochkovian); and Paralogania kummerowi from the upper Silurian "Loganellia" kummerowi zone of the Welsh Borderland, Baltic Beyrichienkalk also in northern Germany and the Netherlands (e.g., Turner 1973, 1999); upper Přidoli, Ohesaare Stage, Latvia; upper Přidoli, upper Jura Formation to Lochkovian basal Tilžè formations, Lithuania; and upper Pridoli to Lower Devonian upper Downton Group in the Welsh Borderland, Great Britain (see Table 1). Only Paralogania ludlowiensis and/or Paralogania sp. cf. P. ludlowiensis is known from the earlier Pridoli Cunningham Creek Formation of southern New Brunswick and from the Moydart Formation of Nova Scotia; this taxon Paralogania ludlowiensis has fewer and wider lateral lappets than Paralogania denisoni. Late Pridoli Paralogania taxa, such as Paralogania kummerowi, are usually associated with Poracanthodes, Gomphonchus and Nostolepis acanthodian scales (e.g., Vergoossen 2000; Turner et al. 2017), all of which include species that are useful zone fossils (Märss et al. 1995; Märss and Mannik 2013; Turner et al. 2017). In particular, these Paralogania species occur with Poracanthodes punctatus, which is the vertebrate zone fossil for the middle-late Pridoli (Märss and Mannik 2013, fig. 2).

Burrow (2011) noted that the vertebrate fauna of the Eastport Formation differs from that of the older Cunningham Creek Formation of nearby southern New Brunswick. As yet the Eastport Formation in New Brunswick has not been intensively searched for vertebrate microremains, but a study is underway.

The Eastport invertebrate fauna, particularly the mollusks and eurypterids, can be correlated with the 'Downtonian' (= Pridoli) of Britain and eastern Canada, in beds that have been considered firmly to be of Silurian age (Bastin and Williams 1914; Churchill-Dickson 2004). Siveter (1989) assigned a Pridoli age to the basal portions of the Eastport Formation based on the presence of the ostracod Nodibeyrichia sp. Miller and Tetlie (2007) also noted that the only Silurian pterygotids from Atlantic Canada and New England are from the Eastport Formation of Maine (Churchill-Dickson 2004). The fish remains described here support these earlier assessments in being typical of the late Pridoli, although a basalmost Lochkovian age cannot be excluded because of the uncertain assessment of some of the remains. 


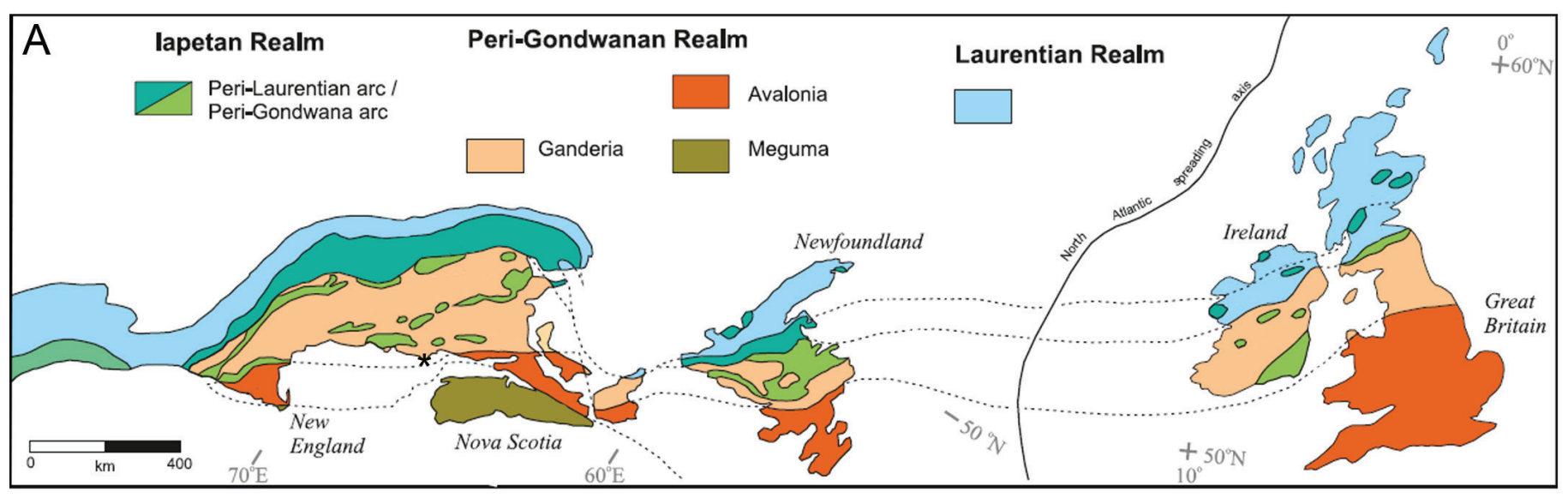

B

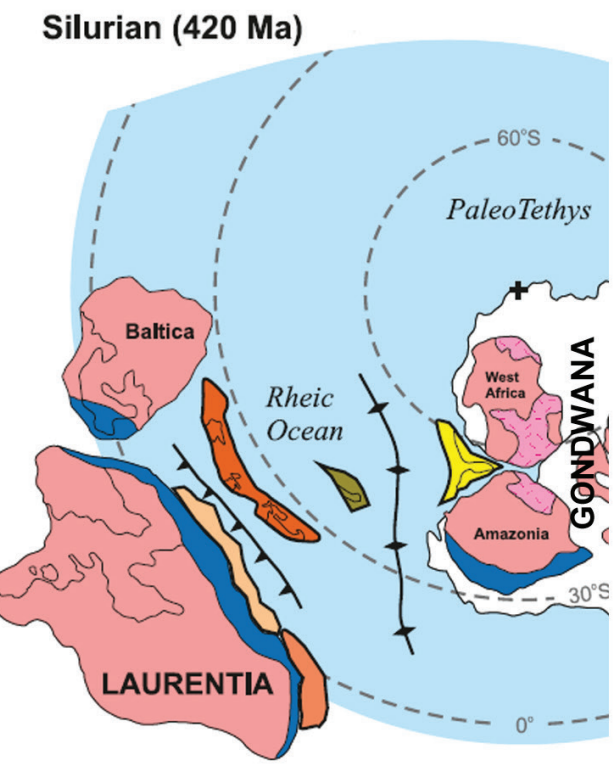

\section{Devonian (375 Ma)}

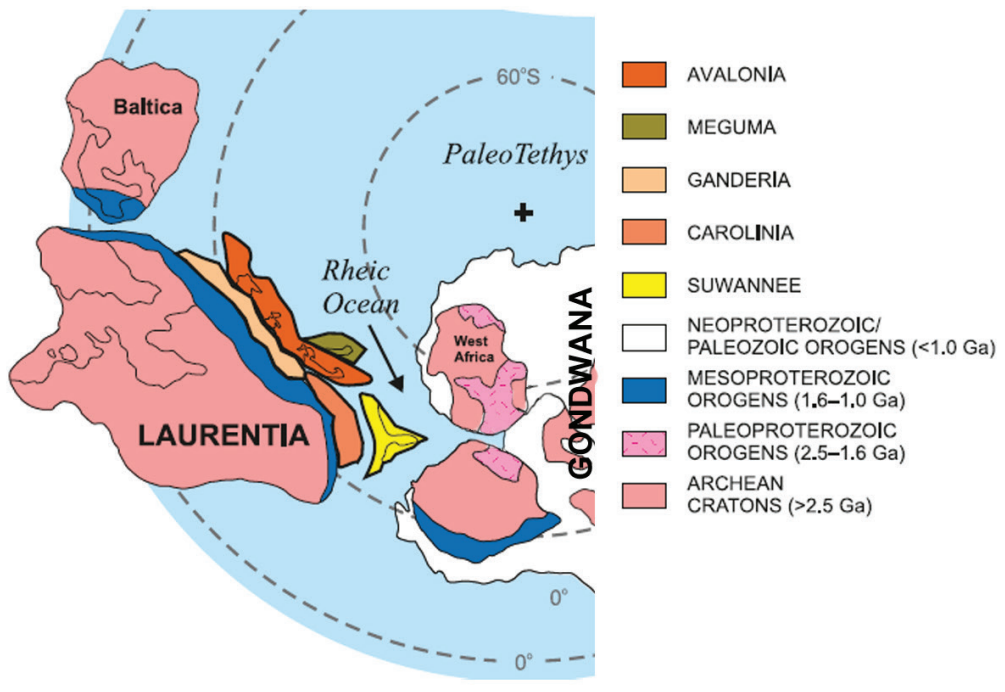

Figure 7. Present, and late Silurian to Early Devonian, extent of terranes of the Maine-New Brunswick region. A, regional distribution of the Appalachian peri-Gondwanan realm (after Pollock et al. 2012, fig. 1; ${ }^{\star}$ Moose Island locality); B, palaeogeography of the region in the late Silurian to Early Devonian (after Pollock et al. 2012, fig. 7).

\section{Paleoenvironment and paleogeography}

Thelodonts, osteostracans, acanthodians and eurypterids are often found associated together along with ostracods and eurypterids in nearshore facies in BAl environments (e.g., Denison 1956; Turner 1999). Boucot et al. (1974, fig. 29) considered the Eastport Formation to be non-marine. The Maine assemblage supports a more marginal marine interpretation. The paleoenvironmental setting was presumably similar to those elsewhere along the shores of the Old Red Sandstone continent, such as the Welsh Borderland, with estuaries and lagoons periodically influenced by nearshore seas to allow dispersal of diadromous fauna (e.g., Turner et al. 2017, fig. 9).

The Silurian-Devonian belt that stretches from Massachusetts, through eastern Maine and into New Brunswick, represents a part of Avalonia that was accreted onto the Ganderian margin of Laurentia during the Acadian orogeny in the middle Paleozoic (e.g., Cocks and Fortey 2009) (Fig. 7).
Late Pridoli to early Lochkovian transgression in this region was succeeded by Lochkovian to Pragian regression related to the impending collision of Avalonia with Laurentia; dextral oblique convergence of Avalonia with the irregular Laurentian margin created local transtensional zones within which terrestrial intraplate volcanism occurred (Tucker et al. 2001; Churchill-Dickson 2004; Pollock et al. 2012; Fig. 7). Boucot et al. (1974, fig. 29) considered the Avalonian Eastport and Knoydart formations (both thought at the time to be Lochkovian) to be non-marine, with the contemporary lower Torbrook Formation (of the Meguma terrane) considered to be marine. This interpretation is consistent with current paleogeographic mapping indicating that accretion of Avalonia with the Ganderian margin of Laurentia occurred by the Pridoli. While Pollock et al. (2012) considered that accretion of Meguma with the Avalonian margin of Laurentia did not occur until the Late Devonian, the presence of nearshore fish such as thelodonts in New Brunswick and Nova Scotia (Blaise et al. 1990, 1991; Turn- 
er 1970, 1986; Turner and Tarling 1982) suggest proximity of the terranes during the middle to late Silurian. Similarly, the fauna described here, plus other fish taxa in common, support a close connection of Avalonia with the Iberian-Armorican terranes by this time (Turner et al. 2017, fig. 10).

Thus far, only the one sample from the Eastport Formation has yielded fish microfossils, but with modern techniques, further sampling should be undertaken. Based on the material described here, the vertebrate fauna of the Eastport Formation has the potential to provide further important information about the timing and duration of the Acadian orogeny, as well as significant information to be used in regional correlations. The provinciality of Silurian fish is one line of evidence used in trying to locate the boundary between the Gander and Avalon terranes in coastal Maine and New Brunswick (H. Berry, pers. comm., July 2012); the Eastport Formation vertebrate assemblage indicates that the terrane boundary is to the west, as indicated by the paleogeographic analysis by Pollock et al. (2012; Fig. 7).

\section{CONCLUSIONS}

The first assemblage of vertebrates to be described from the Eastport Formation of Maine, USA, includes agnathan remains comprising scale fragments of osteostracans and anaspids, and scales of thelodonts. The presence of these fish taxa significantly adds to the middle Paleozoic faunal list for the state. Most of the thelodont scales are assigned to a new species, Paralogania denisoni, and one scale that is questionably assigned to Talivalia sp. Gnathostome remains include scales from ischnacanthiform acanthodians Gomphonchus sandelensis, Poracanthodes punctatus and Nostolepis striata, as well as acanthodian spine and tooth whorl fragments. The fish taxa identified provide information that is significant for regional correlations, especially with eastern Canada, but also to arctic Canada, Greenland, the Welsh Borderlands, the Baltic and Severnaya Zemlya.

Based on our microfossil data, the sample from Moose Island, northern Maine, from the basal Eastport Formation is of late Silurian age. Both the acanthodian Poracanthodes punctatus and the larger-scaled Paralogania spp. were prevalent in the middle-late Pridoli, with only rare records into the earliest Lochkovian. The Maine assemblage of fish supports a later Pridoli age at oldest for the fish-bearing horizon of the Eastport Formation. Further sampling of sedimentary rocks of the Eastport and middle Palaeozoic formations in Maine and adjacent New Brunswick for fish microfossils is necessary to help provide further refinements.

\section{ACKNOWLEDGMENTS}

We thank William Simpson at the FMNH for his help with accessing the collection, and acknowledge the late Robert Denison for his initial field work on the site. Henry Berry (Maine Geological Survey, Augusta) and Randall
Miller (formerly New Brunswick Museum, St John) assisted us with background to the geology. Robert Gastaldo (Colby College, Maine) helped in our efforts to (unsuccessfully) track down other vertebrate material. We thank the Queensland Museum for the provision of basic facilities. Alain Blieck and Hector Botella are thanked for their helpful reviews, and editor Rob Fensome for his insightful and meticulous editorial improvements. This paper is dedicated to our late friend and colleague Art Boucot.

\section{REFERENCES}

Adrain, J.M. and Wilson, M.V.H. 1994. Early Devonian cephalaspids (Vertebrata: Osteostraci: Cornuata) from the southern Mackenzie Mountains, N.W.T. Canada. Journal of Vertebrate Paleontology, 14 (3), pp. 301-319. https://doi.org/10.1080/02724634.1994.10011561

Bastin, E.S. and Williams, H.S. 1914. Eastport folio, Maine. U. S. Geological Survey Geologic Atlas, Folio 192, 15 p.

Berdan, J.M. 1990. The Silurian and Early Devonian biogeography of ostracodes in North America. Geological Society, London, Memoirs, 12 (1), pp. 223-231.

Berg, L.S. 1937. A classification of fish-like vertebrates. Academy of Sciences of the U.S.S.R. Biology Bulletin 1937, pp. 1277-1280 (in English and Russian).

Berg, L.S. 1940. Classification of fishes, both recent and fossil. Trudy Instituta Zoologicheskikh Akademiia Nauk, 5 (2), pp. 85-517.

Blaise, J., Bouyx, E., Dégardin, J.-M., Goujet, D., le Menn, J., and Paris, F. 1990. Données biostratigraphiques nouvelles sur le Silurien de la zone de Meguma en Nouvelle Écosse (Appalaches septentrionales, Canada). Compte-Rendus de l'Academie de Sciences Paris, 310, ser. II, pp. 787-793.

Blaise, J., Bouyx, E., Goujet, D., le Menn, J., and Paris, F. 1991. Le Silurien supérieur de Bear River (zone de Meguma, Nouvelle Écosse): faune, biostratigraphie et implications paléogéographiques. Geobios, 24 (2), pp. 167-182. https://doi.org/10.1016/S0016-6995(91)80004-J

Blieck, A. and Janvier, P. 1999. Silurian-Devonian vertebrate-dominated communities, with particular reference to agnathans. In Paleocommunities: a case study from the Silurian and Lower Devonian. IGCP Project Ecostratigraphy Final Report. Edited by A. J. Boucot and J. D. Lawson. Cambridge University Press, Cambridge, UK, pp. 79-105.

Blom, H. 1999. Vertebrate remains from upper SilurianLower Devonian beds of Hall Land, North Greenland. Geology of Greenland Survey Bulletin, 182, pp. 1-80.

Blom, H., Märss, T., and Miller, C.G. 2002. Silurian and earliest Devonian birkeniid anaspids from the Northern Hemisphere. Earth and Environmental Science Transactions of the Royal Society of Edinburgh, 92 (03), pp. 263-323. (Cover date 2001; issue date 2002) https://doi. org/10.1017/S0263593300000250

Boucot, A.J., Dewey, J.F., Dineley, D.L., Fletcher, R., Fyson, W.K., Griffin, J.G., Hickox, C.F., McKerrow, S., and Ziegler, A.M. 1974. Geology of the Arisaig area. Antigon- 
ish County, Nova Scotia. The Geological Society of America, Special Paper 139, 191 p.

Brotzen, F. 1934. Erster Nachweis von Unterdevon im Ostseegebiete durch Konglomeratgeschiebe mit Fischresten. II Teil (Paläontologie). Zeitschrift Geschiebeforschung, 10, pp. 1-65.

Burrow, C.J. 2011. A partial articulated acanthodian from the Silurian of New Brunswick, Canada. Canadian Journal of Earth Sciences, 48 (9), pp. 1329-1341. https://doi. org/10.1139/e11-023

Burrow, C.J. 2013. Reassessment of Ischnacanthus? scheii Spjeldnaes (Acanthodii, Ischnacanthiformes) from the latest Silurian or earliest Devonian of Ellesmere Island, arctic Canada. Canadian Journal of Earth Sciences, 50 (8), pp. 945-954. https://doi.org/10.1139/cjes-2013-0068

Burrow, C.J. and Rudkin, D. 2014. Oldest near-complete acanthodian: the first vertebrate from the Silurian Bertie Formation Konservat-Lagerstätte, Ontario. PLoS ONE, 9 (8), 7 p. https://doi.org/10.1371/journal.pone.0104171

Burrow, C.J. and Turner, S. 1999. A review of placoderm scales, and their relevance in placoderm phylogeny. Journal of Vertebrate Paleontology, 19(2), pp. 204-219. https://doi.org/10.1080/02724634.1999.10011135

Burrow, C.J., Vergoossen, J.M.J., Turner, S., Uyeno, T., and Thorsteinsson, R. 1999. Microvertebrate assemblages from the upper Silurian of Cornwallis Island, arctic Canada. Canadian Journal of Earth Sciences, 36, pp. 349-361. https://doi.org/10.1139/e98-098

Burrow C. J., Turner, S., Nowlan, G.S., and Denison, R.H. 2013. Vertebrate microremains from the late Silurian of Arisaig, Nova Scotia, Canada. Journal of Paleontology, 87 (6), pp. 1041-1059. https://doi.org/10.1666/12-154

Churchill-Dickson, L. 2004. A late Silurian (Pridolian) age for the Eastport Formation, Maine: a review of the fossil, stratigraphic, and radiometric-age data. Atlantic Geology, 40, pp. 189-195. https://doi.org/10.4138/1038

Churchill-Dickson, L. 2007. Maine's Fossil Record: the Paleozoic. Maine Geological Survey, 500 p.

Claypole, E.W. 1884. Preliminary note on some fossil fishes recently discovered in the Silurian rocks of North America. The American Naturalist, 18 (12), pp. 1222-1226. https://doi.org/10.1086/273832

Claypole, E.W. 1885. On some fish remains recently discovered in the Silurian rocks of Pennsylvania. Proceedings of the American Association for the Advancement of Science, 33rd meeting, 1884, pp. 424-428.

Cocks, L.R.M. and Fortey, R.A. 2009. Avalonia: a longlived terrane in the lower Paleozoic? In Early Paleozoic peri-Gondwana terranes. Edited by M.G. Bassett. Geological Society of London, Special Publication, 325, pp. 141-156. https://doi.org/10.1144/SP325.7

Denison, R.H. 1956. A review of the habitat of the earliest vertebrates. Fieldiana, Geology, 11, pp. 359-457.

DeWindt, J.T. 1974. Acanthodian scales from the Bloomsburg Formation (?middle and upper Silurian) of central Pennsylvania. Journal of Paleontology, 48 (3), pp. 594-595.
Dineley, D.L. and Loeffler, E.J. 1976. Ostracoderm faunas of the Delorme and associated Siluro-Devonian formations, North West Territories, Canada. Special Papers in Palaeontology, 18, iv + $214 \mathrm{p}$.

Dineley, D.L. and Loeffler, E.J. 1993. Chapter 6. Biostratigraphy of the Silurian and Devonian gnathostomes of the Euramerica Province. In Palaeozoic vertebrate biostratigraphy and biogeography. Edited by J.A. Long. Belhaven Press, London, pp. 104-138.

Gates, O. 1977. Geologic map and cross sections of the Eastport quadrangle, Maine: Geologic Map GM-3, scale 1:48 000. Maine Geological Survey. 19 p.

Gegenbaur C. 1874. Grundriß der vergleichenden Anatomie. Wilhelm Engelmann, Leipzig, 660 p. https://doi. org/10.5962/bhl.title.2155

Giffin, E. 1979. Silurian vertebrates from Pennsylvania. Journal of Paleontology, 53(2), pp. 438-445.

Gross, W. 1947. Die Agnathen und Acanthodier des obersilurischen Beyrichienkalks. Palaeontographica A, 96, pp. 91-161.

Gross, W. 1957. Mundzähne und Hautzähne der Acanthodier und Arthrodiren. Palaeontographica A, 109, pp. 1-40.

Gross, W. 1961. Aufbau des Panzers obersilurische Heterostraci und Osteostraci norddeutschlands (Geschiebe) und Oesels. Acta Zoologica, 42, pp. 73-150. https://doi. org/10.1111/j.1463-6395.1961.tb00060.x

Gross, W. 1967. Über Thelodontier-Schuppen. Palaeontographica A, 127, pp. 1-67.

Gross, W. 1971. Downtonische und Dittonische Acanthodier-Reste des Ostseegebietes. Palaeontographica A, 136, pp. 1-82.

Jaekel, O.M.J. 1911. Die Wirbeltiere; eine Übersicht über die fossilen und lebenden Formen. Gebrüder Borntraeger, Berlin, viii+252 p.

Karatajūtè-Talimaa, V. N. 1978. Telodonty Silura i Devona SSSR i Shpitsbergena. [Silurian and Devonian Thelodonts of the USSR and Spitsbergen]. Mokslas, Vilnius, 334 p. [In Russian]

Karatajūtè-Talimaa, V.N. 1997. Taxonomy of loganiid thelodonts. Modern Geology, 21 (1/2), pp. 1-15.

Kiaer, J. 1924. The Downtonian fauna of Norway. I. Anaspi$\mathrm{da}$, with a geological introduction. Videnskapsselskapets Skrifter. I. Matematiske-Naturvidenskapslige Klasse, 6, pp. 1-139.

Lankester, E.R. 1868-1870. A monograph of the fishes of the Old Red Sandstone of Britain. 1. Cephalaspidae. Palaeontographical Society, London, pp. 1-62.

Legault, J.A. 1968. Conodonts and fish remains from the Stonehouse Formation, Arisaig, Nova Scotia. Geological Survey of Canada Bulletin, 165, pp. 1-23.

Mader, H. 1986. Schuppen und Zähne von Acanthodiern und Elasmobranchiern aus dem Unter-Devon Spaniens (Pisces). Göttinger Arbeiten zur Geologie und Paläontologie, 28, pp. 1-59.

Märss, T. and Männik, P. 2013. Revision of Silurian vertebrate biozones and their correlation with the conodont succession. Estonian Journal of Earth Sciences, 62 (4), pp. 
181-204. https://doi.org/10.3176/earth.2013.15

Märss, T., Fredholm, D., Talimaa, V., Turner, S., Jeppsson, L., and Nowlan, G., 1995. Silurian vertebrate biozonal scheme. Geobios, Mémoire Spécial, 19, pp. 369-372. https://doi.org/10.1016/S0016-6995(95)80140-5

Märss, T., Caldwell, M.W., Gagnier, P.-Y., Goujet, D., Männik, P., Martma, T., and Wilson, M. 1998. Distribution of Silurian and Lower Devonian vertebrate microremains and conodonts in the Baillie-Hamilton and Cornwallis Island sections, Canadian Arctic. Proceedings of the Estonian Academy of Sciences, Geology, 47 (2), pp. 51-76.

Märss, T., Wilson, M.V.H., and Thorsteinsson, R. 2002. New thelodont (Agnatha) and possible chondrichthyan (Gnathostomata) taxa established in the Silurian and Lower Devonian of the Canadian Arctic Archipelago. Proceedings of the Estonian Academy of Science, Geology 51 (2), pp. $88-120$.

Märss, T., Wilson, M.V.H., and Thorsteinsson, R. 2006. Silurian and Lower Devonian thelodonts and putative chondrichthyans from the Canadian Arctic Archipelago. Special Papers in Palaeontology, 75, pp. 1-44.

Märss, T., Turner, S., and Karatajūtè-Talimaa, V.N. 2007. Agnatha II. Thelodonti. Volume 1B. In Handbook of Paleoichthyology. Edited by H.-P. Schultze. Verlag F. Pfeil, Munich, 143 pp.

Märss, T., Afanassieva, O., and Blom, H. 2014. Biodiversity of the Silurian osteostracans of the East Baltic. Earth and Environmental Science Transactions of the Royal Society of Edinburgh, 105 (02), pp. 73-148. https://doi. org/10.1017/S1755691014000218

Miller, B.V. and Fyffe, L.R. 2002. Geochronology of the Letete and Waweig formations, Mascarene Group, southwestern New Brunswick. Atlantic Geology 38, pp. 29-36.

Miller, R.F. and Tetlie, O.E. 2007. The presumed synziphosuran Bunodella horrida Matthew, 1889 (Silurian; Cunningham Creek Formation, New Brunswick, Canada) is a eurypterid. Journal of Paleontology, 81 (3), pp. 588-590. https://doi.org/10.1666/05127.1

Owen, R. 1846. Lectures on the comparative anatomy and physiology of the vertebrate animals delivered at the Royal College of Surgeons, England in 1844 and 1846. Part I, Fishes. Longman, Brown, Green and Longmans, London, $\mathrm{xi}+304 \mathrm{p}$.

Pander, C.H. 1856. Monographie der fossilen Fische des silurischen Systems der Russisch-Baltischen Gouvernements. Obersilurische Fische. Buchdruckerei der Kaiserlichen Akademie der Wissenschaften, St. Petersburg, 91 p.

Pollock, J.C., Hibbard, J.P., and van Staal, C.R. 2012. A paleogeographical review of the peri-Gondwanan realm of the Appalachian orogen. Canadian Journal of Earth Sciences, 49, 259-288. https://doi.org/10.1139/e11-049

Siveter, D.J. 1989. Ostracodes. In A global standard for the Silurian System. Edited by C.H. Holland \& M.G. Bassett. National Museum of Wales, Geological Series, 9, pp. 252-264.

Spjeldnaes, N. 1967. Acanthodians from the Siluro-Devo- nian of Ellesmere Island. In International Symposium on the Devonian System, II. Edited by D.H. Oswald. Alberta Society of Petroleum Geologists, Calgary, pp. 807-813.

Stetson, H.C. 1931. Studies on the morphology of the Heterostraci. Journal of Geology, 39, pp. 141-154. https://doi. org/10.1086/623803

Traquair, R.H. 1899. Report on fossil fishes collected by the Geological Survey of Scotland in the Silurian rocks of the south of Scotland. Transactions of the Royal Society of Edinburgh, 39, pp. 827-864. https://doi.org/10.1017/ S0080456800035237

Tucker, R.D., Osberg, P.H., and Berry, H.N. 2001. The geology of a part of Acadia and the nature of the Acadian orogeny across central and eastern Maine. American Journal of Science, 301 (3), pp. 205-260. https://doi.org/10.2475/ ajs.301.3.205

Turner, S. 1970. Timing of the Appalachian/Caledonian orogen contraction. Nature, 227, p. 90. https://doi. org/10.1038/227090a0

Turner, S. 1973. Siluro-Devonian thelodonts from the Welsh Borderland. Journal of the Geological Society, London, 129 (6), pp. 557-584. https://doi.org/10.1144/ gsjgs.129.6.0557

Turner, S. 1984. Studies of Palaeozoic Thelodonti (Craniata: Agnatha). Ph.D. thesis, 2 vols., University of Newcastle-upon-Tyne, $400 \mathrm{p}$.

Turner, S. 1986. Thelodus macintoshi Stetson 1928, the largest known thelodont (Agnatha: Thelodonti). Breviora, 486, pp. 1-18.

Turner, S. 1994. Thermal alteration of microscopic fish remains. Ichthyolith Issues, 13, pp. 25-26.

Turner, S. 1999. Early Silurian to Early Devonian thelodont assemblages and their possible ecological significance. In Palaeocommunities - a case study from the Silurian and Lower Devonian. Edited by A.J. Boucot and J. Lawson. International Geological Correlation Programme 53, Project Ecostratigraphy, Final Report. Cambridge University Press, Cambridge, pp. 42-78.

Turner, S. and Tarling, D. 1982. Thelodont and other agnathan distributions as tests of lower Palaeozoic continental reconstructions. Palaeogeography, Palaeoclimatology, Palaeoecology, 39, pp. 295-311. https://doi. org/10.1016/0031-0182(82)90027-X

Turner, S., Kuglitsch, J.J., and Clark, D.L. 1999. Llandoverian thelodont scales from the Burnt Bluff Group of Wisconsin and Michigan. Journal of Paleontology, 73 (4), pp. 667-676. https://doi.org/10.1017/S0022336000032480

Turner, S., Burrow, C.J., Williams, R.B., and Tarrant, P. 2017. Welsh Borderland bouillabaisse: Lower Old Red Sandstone fish microfossils and their significance. Proceedings of the Geologists' Association, 128, 460-479. https://doi. org/10.1016/j.pgeola.2017.04.006

Valiukevičius, J.J. 1992. First articulated Poracanthodes from the Lower Devonian of Severnaya Zemlya. In Fossil fishes as living animals. Edited by E. Mark-Kurik. Academia 1. Academy of Sciences of Estonia, Tallinn, pp. 193-214.

Valiukevičius, J.J. 2003a. New late Silurian to Middle De- 
vonian acanthodians of the Timan-Pechora region. Acta Geologica Polonica, 53 (3), pp. 209-245.

Valiukevičius, J.J. 2003b. New Silurian nostolepids (Acanthodii, Pisces) of Lithuania. Geologija, 42, pp. 51-68.

Valiukevičius, J.J. 2003c. Devonian acanthodians from Severnaya Zemlya Archipelago (Russia). Geodiversitas, 25, pp. 131-204.

Van Wagoner, N.A. and Dadd, K.A. 2003. A Silurian age for the Passamaquoddy Bay volcanic sequence in southwestern New Brunswick: implications for regional correlations. Geological Society of America Abstracts with Programs 35 (3), p. 79.

Vergoossen, J.M.J. 1997. Revision of poracanthodid acanthodians. In Paleozoic Strata and Fossils of the Eurasian Arctic. Edited by A. Ivanov, M.V.H. Wilson, and A. Zhuravlev. Ichthyolith Issues Special Publication, 3, pp. 44-46.

Vergoossen, J.M.J. 1999. Late Silurian fish microfossils from an east Baltic-derived erratic from Oosterhaule, with a description of new acanthodian taxa. Geologie en Mijnbouw, 78, pp. 231-251. https://doi. org/10.1023/A:1003803814177

Vergoossen, J.M.J. 2000. Acanthodian and chondrichthyan microremains in the Siluro-Devonian of the Welsh Borderland, Great Britain, and their biostratigraphical potential. Courier Forschungsinstitut Senckenberg, 223, pp. 175-199.

Vieth, J. 1980. Thelodontier-, Akanthodier- und Elasmobranchier-Schuppen aus dem Unter-Devon der Kanadischen Arktis (Agnatha, Pisces). Göttinger Arbeiten Geologie und Paläontologie, 23, pp. 1-69.

Von Bitter, P.H., Purnell, M.A., Tetreault, D.K., and Stott,
C.A. 2007. Eramosa Lagerstätte - exceptionally preserved soft-bodied biotas with shallow-marine shelly and bioturbating organisms (Silurian, Ontario, Canada). Geology, 35 (10), pp. 879-882. https://doi.org/10.1130/ G23894A.1

White, C.E. and Barr, S.M. 2012. Meguma terrane revisited: stratigraphy, metamorphism, paleontology, and provenance. Geoscience Canada, 39 (1), pp. 8-12. https://journals.lib.unb.ca/index.php/GC/article/view/19450/21004

White, C. E. and Barr, S. M. 2017, Stratigraphy and depositional setting of the Silurian-Devonian Rockville Notch Group, Meguma terrane, Nova Scotia, Canada. Atlantic Geology, 53, pp. 337-365. https://doi.org/10.4138/atlgeol.2017.015

Woodward, A.S. 1891. Catalogue of the fossil fishes in the British Museum (Natural History). Part II. British Museum (Natural History), London, 567 p.

Young, G.C. 1981. Biogeography of Devonian vertebrates. Alcheringa, 5, pp. 225-243. https://doi. org/10.1080/03115518108567003

Žigaitè, Ž., Richter, M., Karatajūtè-Talimaa, V., and Smith, M.M. 2013a. Tissue diversity and evolutionary trends of the dermal skeleton of Silurian thelodonts. Historical Biology: An International Journal of Paleobiology, 25 (2), pp. 143154. https://doi.org/10.1080/08912963. 2013.766184

Žigaitè, Ž., Karatajūtè-Talimaa, V., Goujet, D., and Blom, H. 2013b. Thelodont scales from the Lower and Middle Devonian Andree Land Group, Spitsbergen. GFF, 135 (1), pp. 57-73. https://doi.org/10.1080/11035897.2012. 762549 